\title{
Recombinant Soluble Human CD4 Protein
}

National Cancer Institute

\section{Source}

National Cancer Institute. Recombinant Soluble Human CD4 Protein. NCI Thesaurus.

Code C2342.

A recombinant human soluble CD4 with antiviral activity. Recombinant human soluble CD4 has the amino terminus but not the T-cell binding domain of the endogenous CD4 antigen. This soluble CD4 protein competitively binds to envelope glycoprotein (gp120) of human immuno deficiency virus (HIV) resulting in inhibition of interaction between gp120 and the endogenous CD4 antigen, thereby blocking viral recognition of CD4 and subsequent entry of HIV into CD4 bearing cells. 